\section{Infrastructure Indices: \\ Comparative Analysis of Performance, Risk and Representation of Global Listed Proxies}

\section{Dimitar Lambrev}

PhD Student, International Joint Cross-Border PhD Program, University of Applied Science Burgenland, Austria

1519001016@fh-burgenland.at

\begin{abstract}
Faced with historically low interest rates, investors are looking further into illiquid assets such as infrastructure in search of alternative sources of income, better diversification and a long-term investment perspective. This paper analyzes the key performance and risk characteristics of the EDHECinfra global unlisted infrastructure equity index when compared to the main global listed infrastructure indices during the 2001-2018 period. The descriptive statistics method is applied to determine the representation of the benchmarks commonly used by investors considering infrastructure investments. For the purpose of the market beta analysis, the $\mathrm{MSCl}$ World index is also used as a global equities proxy in a linear regression model.

Listed infrastructure is often considered as an income-yielding and defensive equity strategy that provides a liquid proxy for alternative assets (e.g., infrastructure). However, the paper results indicate that the net effect of investing in listed infrastructure remains questionable, even unknown. Recent empirical findings demonstrate divergent stands on benchmarking infrastructure. The high correlation of the main listed infrastructure indices with the broad equity index $\mathrm{MSCl}$ World and the inconsistency of research results thus far suggest that infrastructure is an ill-defined investment category within the listed infrastructure space with lacking reliable and useful benchmarking. The commonly used and far-reaching classification of companies with broad industrial nature and business activities that are less relevant to infrastructure may affect the overall representation of the legitimate characteristics of the infrastructure asset class amid the growing enthusiasm among investors.
\end{abstract}

Keywords: infrastructure, index, benchmarking, listed equity, performance analysis

\section{Introduction}

Institutional investments in infrastructure have grown in popularity across the financing sector and have been a highly discussed topic in recent years. In terms of public policy, budget deficits have triggered governments to more frequently engage in cooperation with the private sector for the development and financing of infrastructure projects. The political willingness of many Western European countries has routinely created the demand for pension funds and insurers to invest in infrastructure in an effort to support the larger economy. Such investments are intended to help meet
ORIGINAL SCIENTIFIC PAPER

RECEIVED: AUGUST 2019

REVISED: SEPTEMBER 2019

ACCEPTED: SEPTEMBER 2019

DOI: 10.2478/ngoe-2019-0011

UDK: 338.49:311.141

JEL: G10, G11, G15, G23, H54

Citation: Lambrev, D. (2019).

Infrastructure Indices: Comparative

Analysis of Performance, Risk and

Representation of Global Listed Proxies. Naše gospodarstvo/Our Economy, 65(3), 23-39. DOI: 10.2478/ngoe-2019-0011

\section{NG OE}

NAŠE GOSPODARSTVO OUR ECONOMY

vol.65: No. $3: 2019$

pp. $23-39$ 
long-term investment needs and generate an attractive risk-return profile. This paper aims at capturing the key investment characteristics of infrastructure and answering the research question of whether the performance of global listed indices gives an adequate representation when compared with an unlisted infrastructure proxy.

Many investors have become interested in infrastructure as an 'asset class' due to its appealing characteristics (Inderst, 2010). Infrastructure investments potentially offer some useful characteristics for pension funds and insurance companies that have to match (often inflation-linked) annuity-type liabilities. Infrastructure assets are often expected to have long-term, predictable cash flows; low sensitivity to business cycles; low risk; and low correlations to other asset classes. Furthermore, project finance debt has exhibited relatively favorable default and recovery rates compared to corporate debt between 1983 and 2017 (Moody’s, 2018). However, a recent review (Amenc et al., 2019) including documentation and performance data of 144 investment products indicates that listed infrastructure companies often can be risky and expensive while failing to deliver better value.

Infrastructure investments appear as an attractive investment opportunity not only from a risk-return point of view but also from a prudential perspective. Benefiting from lower capital requirements according to the Solvency II regulatory framework for investing in higher quality infrastructure opportunities (European Commission 2016, 2017) has also triggered a growing enthusiasm across investors. Asset owners are also re-discovering 'long-term investing', trying to capture an 'illiquidity risk premium' from infrastructure.

Following this introduction of the infrastructure asset class and motivation of investors when considering investment in infrastructure (section I), this paper outlines the methodological approach (sector II), namely a quantitative analysis used to determine and validate the representation and relevance of the broad listed infrastructure equity indices. The findings from previous studies (sector III) provide some empirical evidence of the importance and benefits of including infrastructure in the investment portfolio mix, as well as expressing some concerns around the foundation and validity of the asset class. However, recent academic research is based mostly on listed asset performance due to a lack of direct performance data. The research gap can be attributed to the data limitations concerning the direct infrastructure performance, which this paper aims to cover to a certain extent by using a private unlisted index. As a next step, a comparative analysis (section IV) of the methodology standards used in building the global indices is undertaken to outline the main characteristics and differences. In section V, the author measures the performance and risk of various global listed infrastructure indices relative to an unlisted infrastructure equity index recently published by the Ecole des Hautes Etudes
Commerciales du Nord Infrastructure Institute (EDHEC). The comparison of the various industry-provided thematic indices aims at determining the degree of representation of the main listed infrastructure indices. For that purpose, the author uses quarterly return data for all indices for the period from $1^{\text {st }}$ January 2007 to $31^{\text {st }}$ December 2018 (excluding the Macquarie global index, which was discontinued at the end of 2016). The data used in this paper are based on availability as of $30^{\text {th }}$ June 2019. The paper reports the findings from the underlying analysis and draws conclusion in section VI.

\section{Methodological Approach}

This paper is intended to provide a comprehensive review of the performance and key risk parameters of the main global listed infrastructure indices by using a descriptive statistics method. A quantitative analysis (including covariance, correlation, and linear regression analysis) of sample market index data has been performed to determine the representation, validity and relevance of the main listed infrastructure indices. The underlying risk and return analysis consists of measuring the risk-adjusted performance, downside protection, and diversification effect as well as equity market beta tests of listed infrastructure indices compared to the EDHECinfra unlisted global infrastructure index and the MSCI World as a global stock market proxy. Further, the paper seeks to provide a detailed description of the key elements in the methodology of those infrastructure indices and thus to enable an adequate comparison of the index building approaches.

Amid the growing popularity of the asset class among institutional investors, the results of this study are targeted to address the need for implementing better-defined benchmarks in the infrastructure space that can help investors in their investment, risk management and asset allocation decisions.

\section{Literature Review}

A recent Vanguard study of the listed infrastructure equity market (Geysen, 2018) demonstrated the reduced volatility and diversification effect of an overweight to infrastructure asset class by utilizing a mean-variance approach during the historical period of analysis. However, the paper concluded that the benefits of the enhanced portfolio's risk-adjusted returns need to be weighed against the concentration risk and arguably superior inflation hedge when considering an overweight allocation to infrastructure asset class.

Empirical findings challenge the relationship between listed and unlisted infrastructure investments. Based on an asset 
pricing approach (Bianchi \& Drew, 2014) on a sub-set of listed stocks in the utility sector derived from publicly listed global and regional infrastructure indices, infrastructure returns did not exhibit any additional premium compared to global stocks or global utilities industry indices, and thus infrastructure could not be defined as a separate asset class. A potential additional return from unlisted infrastructure was considered a function of idiosyncratic risk, infrastructure asset selection, liquidity risk, equity valuation risk or a combination of these. In contrast, Moss (2014) showed the benefit of including an unlisted portfolio consisting of a representative sample of listed infrastructure funds with a neutral to positive impact on the portfolio performance as well as liquidity and diversification effects when using the various databases.

The strong risk-adjusted performance and portfolio diversification benefits of unlisted infrastructure versus listed infrastructure and other listed assets (Newell et al., 2011) underline the increased importance of investing in infrastructure by pension's funds, sovereign wealth funds and insurance companies. The unlisted portfolio performed strongly during the global financial crisis (GFC), thereby activating some considerations regarding the development of an effective asset class.

In replicating an approach consisting of selecting stocks by sectors and levels of income generated from infrastructure activities (set at 90\%) paired with testing the performance of various global industry-provided thematic stock indices (e.g. MSCI Infrastructure World), Blanc-Brude and Whittaker (2015) suggested that the infrastructure indices outperform the market benchmark MSCI, likely due to the implicit value factor represented by infrastructure firms; however, they exhibited drawdown risk and tail risk as well as high correlation with the broader stock market during the entire length of the business/credit cycles. Conversely, a pre-defined portfolio of five stocks (representing approximately 280 individual equity stakes) listed on the London Stock Exchange illustrated very little correlation with the market from a price-return perspective, and no correlation at all (i.e., market beta of zero) on a total return basis as a result of the high payout ratio and frequency of those payouts.

In a follow-up publication, EDHEC (Blanc-Brude et al., 2017) indicated the significant outperformance of a broad market index of private infrastructure when compared to the public equity market reference index over the 2000-2016 period, as it also did not suffer from any drawdowns during the market collapses in the 2007-2011 period. By using a bottom-up approach to compare the risk-adjusted performance, the authors showed that most segments of the private index universe, such as infrastructure projects and contracted infrastructure, exhibited an attractive risk-reward profile due to the greater return and lower value-at-risk (VaR); however, they noted the obstacle of having bulky and illiquid investments at the asset allocation level in the absence of well-diversified infrastructure products.

At the end of a series of scientific research papers on the listed infrastructure topic, EDHEC reported false claims and a misleading narrative on listed infrastructure, as most investments could not be considered infrastructure under any definition (Amenc et al., 2017). The reputation of the infrastructure asset class might be compromised due to the lack of transparency around the so-called asset class and the growing appetite of institutional investors (reported at USD 57bn in 2017). EDHEC labels the so-called asset class 'fake infra', as it arguably poses a threat to the infrastructure investment sector by not fulfilling the characteristics of infrastructure. The research on actual constituents of both passive and active listed infrastructure (often campaigned by managers under the broad infrastructure definition) indicates that listed infrastructure has failed to deliver the same performance as unlisted infrastructure investments, namely on key elements such as premium returns, reduced volatility, diversification, downside protection and inflation-linked predictable cash flows.

Controversially, previous academic studies (e.g., Oyedele et al., 2012) supported the inclusion of infrastructure in a broader multi-asset portfolio mix. The study compared global listed infrastructure performance with other asset classes such as stocks, bonds, real estate, hedge funds and private equity during the 2001-2010 period and found that a systematic allocation between $10 \%$ and $18 \%$ to infrastructure contributes more to risk reductions (i.e., improved diversification), instead of enhancing the return of the overall portfolio mix. Obviously, recent empirical findings show the imminent need to address the issue of treating listed infrastructure and finding an appropriate benchmarking tool as a venue for further research work and studies.

\section{Overview of Global Infrastructure Indices}

Infrastructure companies can be described as businesses with long-term, steady and predicable cash flows coming from providing essential services (Inderst, 2010). Investments in real assets like infrastructure companies benefit from very minimal price-elasticity of demand (due to the monopolistic nature of the business), often inflation hedge and little exposure to the business cycle. Institutional investors are continuing to look into infrastructure investments as part of their portfolio. As a result of the growing interest in the asset class, the need to determine the role of infrastructure in the multi-asset portfolio has become imminent.

Within the investment community, infrastructure has various definitions and views with respect to the relation to global indices. Even the listed infrastructure space offers no 
universally agreed definition of infrastructure. Generally, infrastructure has a unique definition due to its characteristics and high degree of heterogeneity among sectors. Infrastructure can be defined as the basic facilities, service installations and physical assets needed for providing an essential service to a community or society, such as transportation and communication systems, water and power lines, schools, hospitals, renewable energy, and so on (Inderst, 2010).

In fact, the meaning of 'infrastructure' depends on the definition used for it. The definition of infrastructure by the World Bank (online) dictates the infrastructure services provided by a project, namely electricity generation, transmission and distribution, natural gas transmission and distribution, information and communication technologies (ICT) and transportation.

OECD (2002) defines infrastructure as the system of public works in a country, state or region, including roads, utility lines and public buildings. In the investment context, this usually translates into economic infrastructure (i.e. transport, utilities, communication, and renewable energy) as well as social infrastructure. Infrastructure assets are characterized by capital intensity, longevity, economies of scale, complexity and heterogeneity (Della Croce et al., (2015). The prudential framework of Solvency II (EC, 2016) specifies the definition of infrastructure as physical structures, facilities, systems and/or networks that are essential to the public and/or society, whereas infrastructure project entity or a special purpose vehicle (SPV) refers to a legal entity which does not perform any other functions than to own, finance, develop or operate infrastructure assets.

Defining the infrastructure asset class has been at the center of recent debates with respect to asset allocation strategies or prudential purposes. The EDHEC institute (Blanc-Brude et al., 2017) is believed to have addressed the multiple biases created by data collection from the infrastructure market and the potentially skewed representation of infrastructure as a result of larger investments in the investable market by using a sample universe of infrastructure investments.

Previous empirical works (Geysen, 2018) suggest that infrastructure investments create diversification benefits, improve the risk-return profile of the portfolio and certainly can be helpful in the asset management context. In this paper, the author searches for a meaningful evidence of those benefits, mainly by comparing the performance of the EDHEC private infrastructure equity index to the broader infrastructure benchmarks in the listed infrastructure space. For the purpose of this scientific analysis, the author initially examines the composition, structure, and methodology of eight global infrastructure indices, including one unlisted global private infrastructure equity index, six global listed infrastructure indices and one global listed equity index.

\section{A. Index Methodology Comparison}

\section{1) EDHEC Global Unlisted Infrastructure Equity Index ('EDHECinfra')}

The EDHEC global unlisted infrastructure equity index is a market value-weighted representation of the global private infrastructure equity market. The EDHECinfra private infrastructure equity investments index is a sample-based universe of investable private infrastructure companies spanning more than 25 countries (mostly OECD and some emerging markets) over 18 years, going back to the year 2000. The index may be argued to offer market-adequate representation of the preferences of buyers and sellers of unlisted infrastructure investments. Index constituents contain all business models including both infrastructure projects (SPVs) and infrastructure corporates.

The EDHECinfra index provides an alternative framework of reference relevant to the infrastructure asset class as opposed to the investment categories inherited from private equity and real estate universes. The index selects companies from the specific sub-industries of The Infrastructure Company Classification Standard (TICCS) designed to capture the characteristics of infrastructure investments. The TICCS (see Appendix A) is a four pillar multi-company classification system consisting of three business risk models, various industrial super-classes (corresponding to 30 industry classes and 68 individual asset-level subclasses), four geo-economic exposures and two corporate-governance forms. These filters correspond to the Global Industry Classification Standard (GICS) classification of infrastructure companies as described in Appendix B. In order to be included in the EDHECinfra broad market indices, an investable infrastructure company needs to qualify under TICCS classification as meeting one of the eligibility criteria (EDHEC, 2018).

\section{2) Dow Jones Brookfield Global Infrastructure Index ('DJ Brookfield')}

Dow Jones Brookfield Global Infrastructure index measures the performance of approximately 100 companies worldwide that are owners and operators of pure-play infrastructure assets with at least $70 \%$ of cash flows derived from infrastructure lines of business. The index is produced jointly by S\&P Dow Jones Indices and Brookfield Asset Management and, based on GICS classification system (see Appendix B), covers primarily communication, energy, industrials, real estate, and utilities sectors. The index has a modified market capitalization weighting with a total market cap of USD 1.13 trillion, representing 101 firms as of 30 ${ }^{\text {th }}$ June 2019 (Standard and Poor's Dow Jones Indices, 2019). 


\section{3) MSCI Europe Infrastructure Index ('MSCI’)}

The MSCI Europe Infrastructure Index captures the global opportunity set of listed companies that are owners or operators of infrastructure assets. Constituents are selected from the equity universe of MSCI Europe, the parent index, which covers mid and large cap securities across the 15 developed market countries in Europe. All index constituents are categorized into 13 subindustries according to GICS standard, which MSCI then aggregates and groups into 5 infrastructure sectors: telecommunications, utilities, energy, transportation and social (MSCI defined infrastructure sectors not as official GICS sectors but as aggregated subsets of GICS sub-industries based on the MSCI Infrastructure Indexes Methodology). As of $30^{\text {th }}$ June 2019, the total market capitalization was reported at EUR 637bn, consisting of 51 constituents (MSCI, 2017).

\section{4) RARE Global Infrastructure Index ('RARE')}

The RARE Global Infrastructure index tracks the performance of a portfolio of global infrastructure-related equities domiciled in domestic, developed and emerging international markets. This smart beta index seeks to provide focused exposure to infrastructure companies in the transportation, energy, utilities, communication and social services sectors according to GICS. Infrastructure assets include physical structures, networks, developments and projects that communities and economies require to function and grow. Weighting of the index is determined by free float market capitalization, infrastructure exposure and region. The market cap was reported at EUR 2.02tn across 120 constituents as of 28 $8^{\text {th }}$ June 2019 (Legg Mason, 2017).

\section{5) S\&P Global Infrastructure Total Return Index ('S\&P’)}

The S\&P Global Infrastructure Index, as part of the S\&P thematic indices, is designed to track 75 listed infrastructure companies across three distinct infrastructure clusters: energy, transportation, and utilities (telecommunication infrastructure is excluded). The sectorial weighting is determined by the fixed number of constituents. First, 15 emerging market stocks are selected; then, the developed market is sorted out with 30 stocks in transportation (i.e., $40 \%$ weight), 30 stocks in utilities (i.e., $40 \%$ weight) and 15 energy infrastructure companies (i.e., $20 \%$ weight) based on a float-adjusted market capitalization. Stocks with lower market capitalization are allowed if the index provides less than 75 companies in total. Total market capitalization was USD 1.48tn as of $28^{\text {th }}$ June 2019 (Standard \& Poor's, 2019).

6) STOXX Global Broad Infrastructure Index Gross Return ('STOXX')

The STOXX Global Broad Infrastructure Index is derived from a portfolio of stocks that have at least $50 \%$ of the total most recent annual revenues coming from infrastructure business and/or supplying goods or services to companies from the infrastructure industry. The index includes all developed and emerging markets of the STOXX Global Total Market Index. Its universe is derived from all stocks across the communications, energy, government outsourcing/social, transportation and utilities sectors according to the GICS standard. The index is weighted according to free-float market capitalization with additional weighting cap factors (e.g. sector cap of 40\%). Market capitalization was EUR 1.77bn as of $28^{\text {th }}$ June 2019 STOXX, 2019).

7) Macquarie Global Infrastructure Total Return Index ('Macquarie')

The Macquarie Global Infrastructure index reflects the stock performance of companies engaged principally in the management, ownership and/or operation of infrastructure and utility assets. The inde $\mathrm{x}$ covers assets classified by GICS such as transportation, telecommunications, social infrastructure and utilities. The weighting is done using a free-float methodology. The index history goes back to July 2000; however, this index was discontinued in 2016 (Macquarie, 2005). The alternative index series to be used is FTSE Global Core Infrastructure Index (see below).

\section{8) FTSE Global Core Infrastructure Index ('FTSE')}

The FTSE Global Core Infrastructure Index reflects the performance of infrastructure and infrastructure-related listed securities worldwide, which are categorized in accordance with the Industry Classification Benchmark (ICB), the global standard for industry sector analysis. Constituents are screened according to ICB subsectors that meet FTSE's definition of core infrastructure, which is typically characterized as structures and networks with conveyance of goods, services, information/data, people, energy and necessities. Weights are capped as follows: transportation, $30 \%$; utilities, 50\%; and others (e.g., telecommunication, pipelines, REITs, etc.), $20 \%$. The index has a free float-adjusted market capitalization, which was reported at EUR 2.75bn as of $30^{\text {th }}$ June 2019 (FTSE Russell, 2019).

\section{9) MSCI World Index ('MSCI World')}

The MSCI World Index in EUR is a free-float weighted equity index that identifies eligible equity securities worldwide. This global benchmark measures and captures large-cap and mid-cap representatives across 23 developed markets. The index covers approximately $85 \%$ of the free float-adjusted market capitalization in each country (MSCI, 2019). The MSCI World index is used for comparison purposes only as a global stock market proxy. 


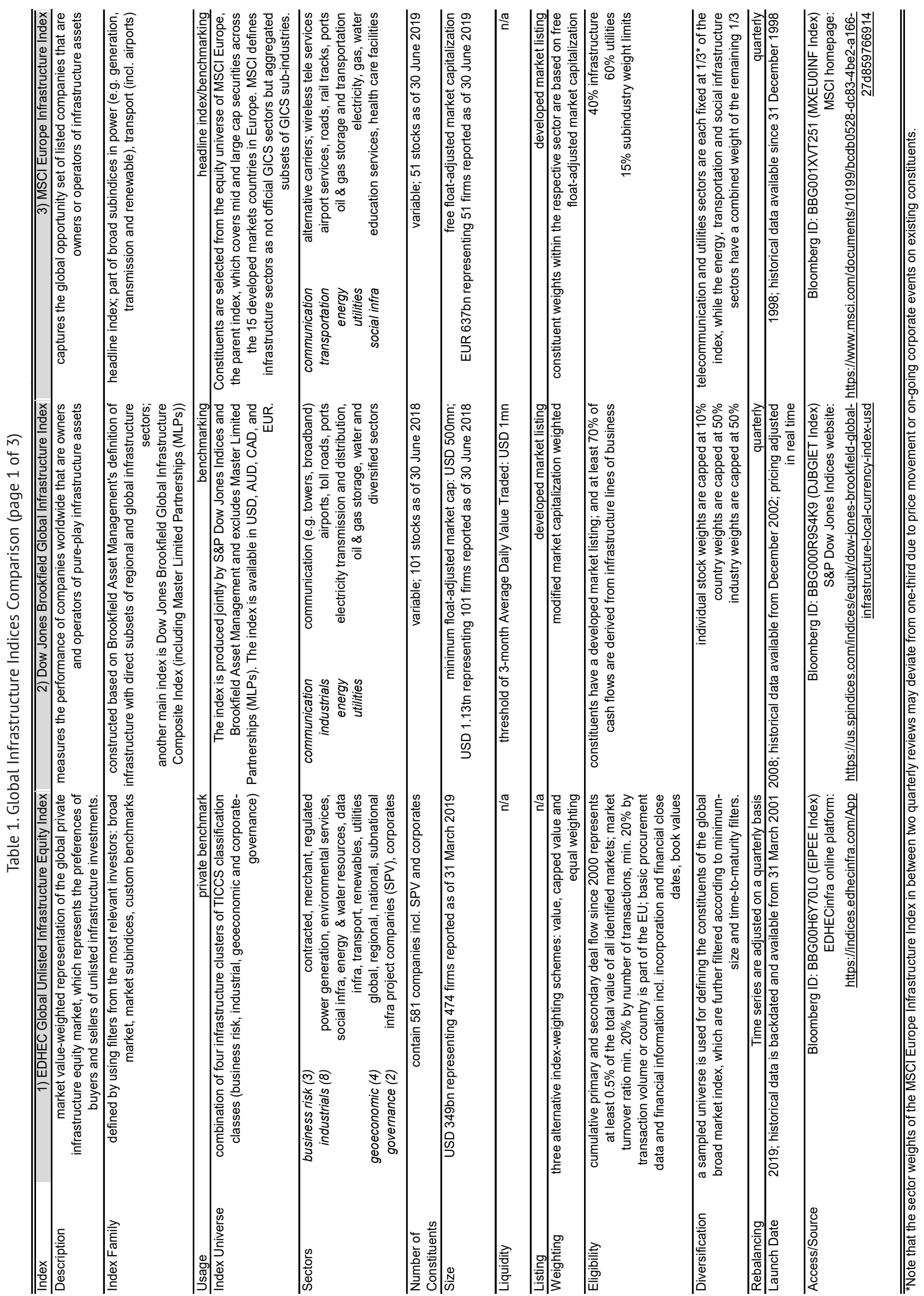




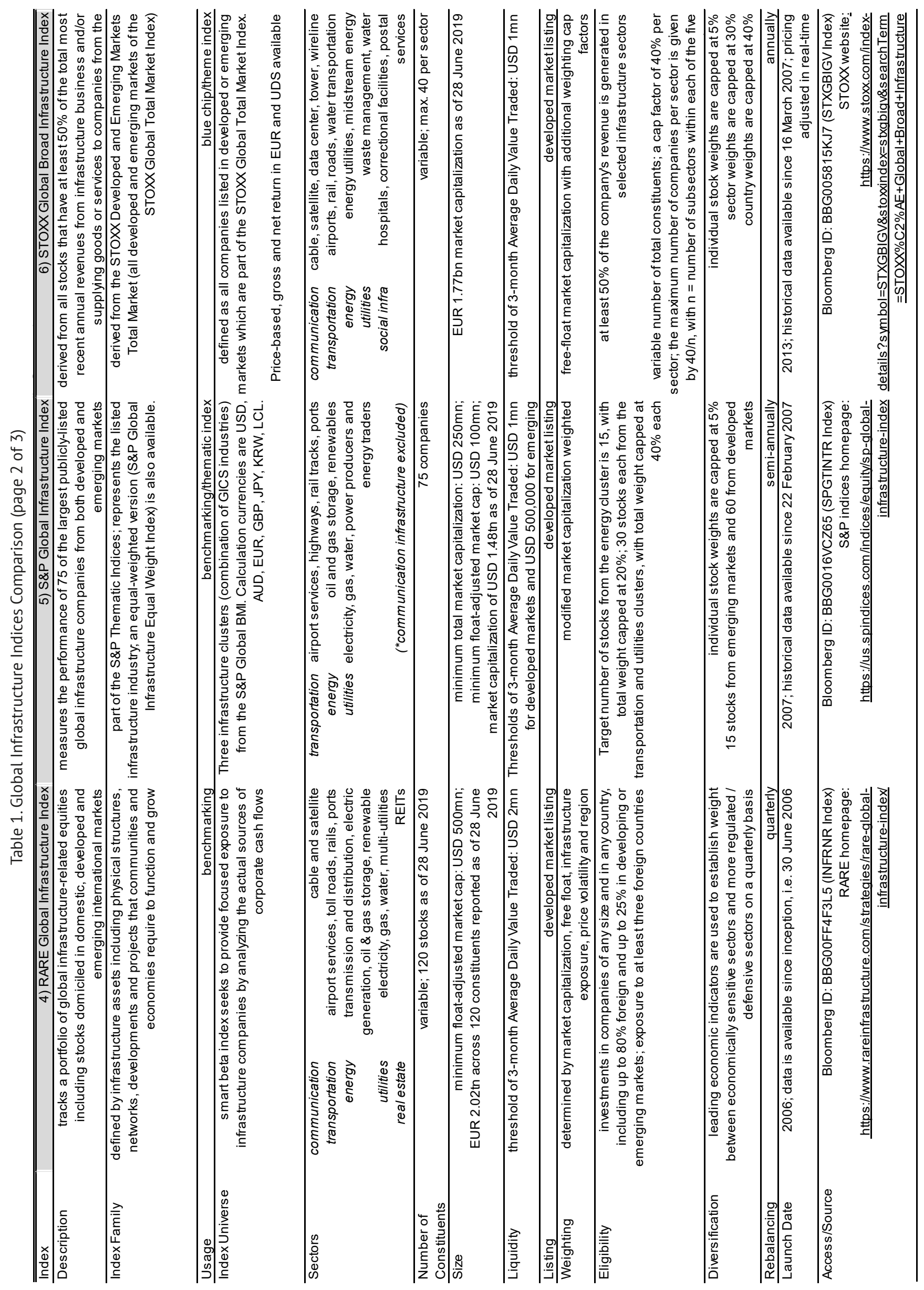




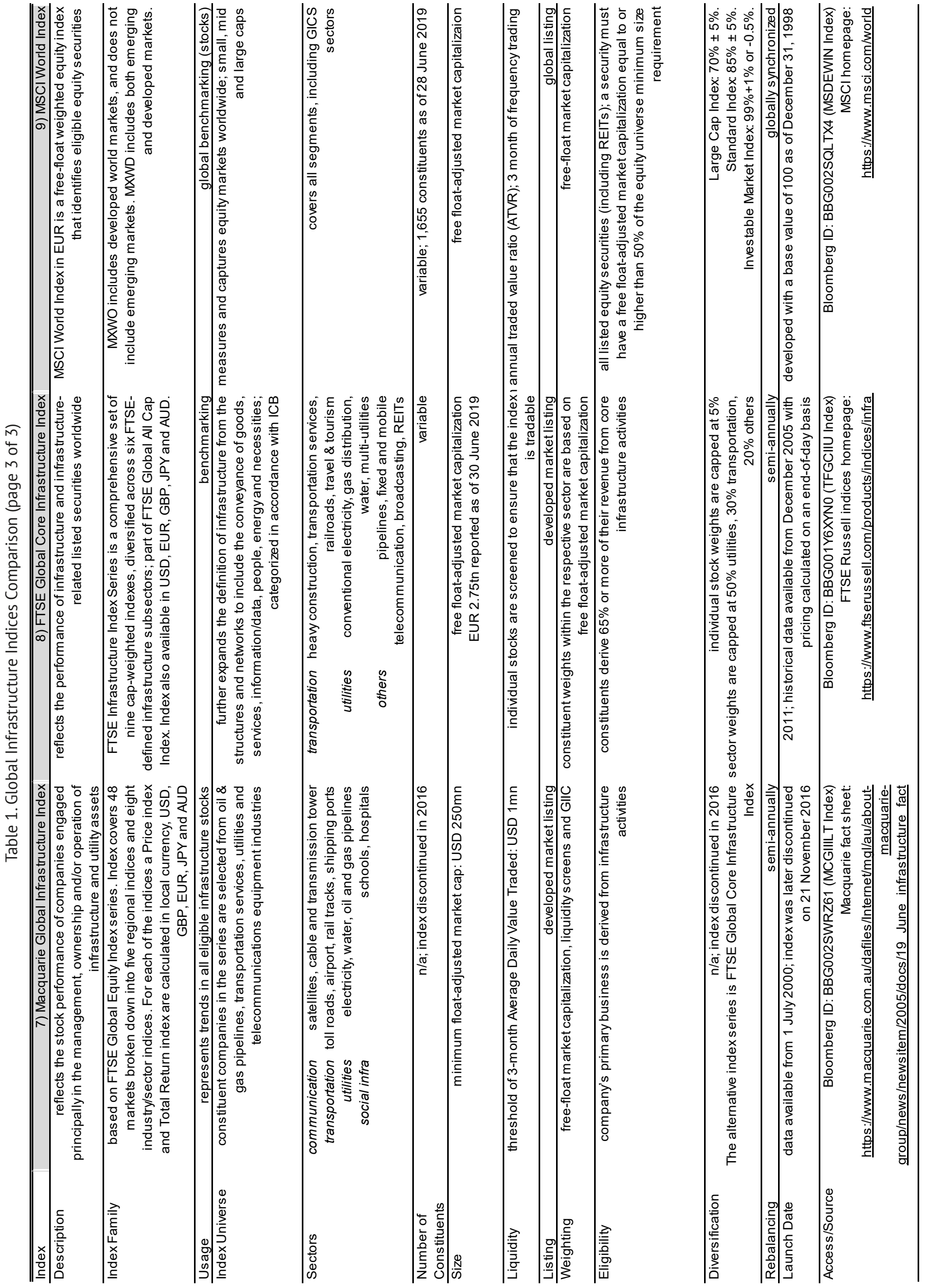


B. Summary of index compositional breakdown - definition, scope, methodology, weighting, eligibility and classification

A common consensus among the global infrastructure indices is that infrastructure is usually defined by assets representing physical structures, networks, developments and projects that communities and economies require to properly function and develop. FTSE further expands the definition in accordance with the ICB classification standard.

In terms of scope, all indices (except MSCI World, which is a pure global equity index used for comparison purposes) measure the performance of global infrastructure companies that are owners or operators of infrastructure assets. EDHECinfra further defines its investment universe to represent the preferences of buyers and sellers of the unlisted infrastructure investments. Each index is based on its own methodology in an effort to capture the stock performance of infrastructure companies. In this respect, constituents need to provide a meaningful portion of their cash flows to derive from infrastructure lines of business ranging from $50 \%$ (e.g., STOXX) to at least $70 \%$ of the company's cash flows (e.g., DJ Brookfield). On the other hand, EDHECinfra utilizes a sampled universe for defining the constituents of its global index, which include a large range of categories to ensure that any private infrastructure company worldwide can be included provided it fulfils the eligibility criteria.

The weight of developed markets (consisting predominantly of North America and Europe) appears consistent across the indices, with the exception of the S\&P index carrying a minimum weight of $20 \%$ for constituents from emerging markets. A broad comparison of the main global listed indices indicates that a free-float market capitalization is the most common weighting method for the vast majority, and some indices provide scaled weightings to allow for a specific contribution from particular sectors (e.g. MSCI, S\&P, STOXX, FTSE).

However, the subject indices methodology analysis also shows a fundamental difference in the classification of the infrastructure exposures within an index. A review of the classification standard maintained by the global listed indices, namely the GICS, has determined inconsistent categorization of some index constituents. For instance, many road operating companies are often categorized as construction firms, while airport operators and airline-catering firms are often not distinguished. Further, project finance vehicles (e.g. SPVs) are categorized as "financials" rather than as infrastructure companies with a specific sectorial exposure in developing or operating an infrastructure business. Such differences between the main global listed indices and the
EDHECinfra index have a meaningful impact on performance, as discussed further in this paper. Nevertheless, the benefits that infrastructure investment delivers to investors can only be achieved by creating exposure to a broad base of assets or at least replicating the characteristics of the infrastructure market.

\section{Return and Risk Analysis}

In the subsequent analysis, the author used unhedged USD and EUR denominated data to facilitate an equitable comparison amongst index providers. (Please note that not all indices provide hedged versions of their indices or performance data on a local basis.) For the purpose of this study, the author uses quarterly data from the Bloomberg terminal to examine all indices based on availability as of $30^{\text {th }}$ June 2019. The 3-month Euribor is used a risk-free interest rate benchmark, reported at $-0.346 \%$ as of $1^{\text {st }}$ July 2019 (Euribor, online).

\section{A. Performance}

Generally, listed infrastructure has indicated a steady outperformance relative to global equities over the last decade. The companies in those indices have delivered better returns despite major financial events such as GFC (with the exception of MSCI infrastructure index), whereas the global stocks (i.e., MSCI World) suffered higher drawdowns and lower returns during the same period, respectively. However, the EDHECinfra index has consistently delivered superior returns (between 11.9\% and 16.4\%) compared to the listed infrastructure indices (between $-1.5 \%$ and $12.9 \%$ during the entire study period of 2001-2018).

Table 2. Annualized Returns

\begin{tabular}{lccccc} 
& 3 years & 5 years & 10 years & 12 years & 18 years \\
\hline EDHECinfra & $11.9 \%$ & $13.4 \%$ & $16.4 \%$ & $15.9 \%$ & $16.1 \%$ \\
\hline DJ Brookfield & $4.9 \%$ & $8.1 \%$ & $12.9 \%$ & $8.1 \%$ & $10.8 \%$ \\
\hline MSCI & $-1.5 \%$ & $3.7 \%$ & $3.3 \%$ & $0.4 \%$ & $1.2 \%$ \\
\hline RARE & $7.8 \%$ & $5.7 \%$ & $8.1 \%$ & $5.9 \%$ & $6.2 \%$ \\
\hline S\&P & $7.2 \%$ & $4.5 \%$ & $8.5 \%$ & $5.1 \%$ & $10.2 \%$ \\
\hline STOXX & $5.9 \%$ & $4.5 \%$ & $8.6 \%$ & $5.5 \%$ & $5.5 \%$ \\
\hline Macquarie & $7.4 \%$ & $6.4 \%$ & $7.0 \%$ & $4.1 \%$ & $6.8 \%$ \\
\hline FTSE & $9.4 \%$ & $7.0 \%$ & $10.0 \%$ & $7.3 \%$ & $8.5 \%$ \\
\hline MSCI World & $5.1 \%$ & $9.1 \%$ & $12.2 \%$ & $6.5 \%$ & $5.0 \%$ \\
\hline
\end{tabular}

Source: Author's calculation baased on Bloomberg (2019).

A recent survey (Amenc et al., 2019) including more than 300 respondents, representing USD 10 trillion in assets 
Figure 1. Cumulative Returns since 2007

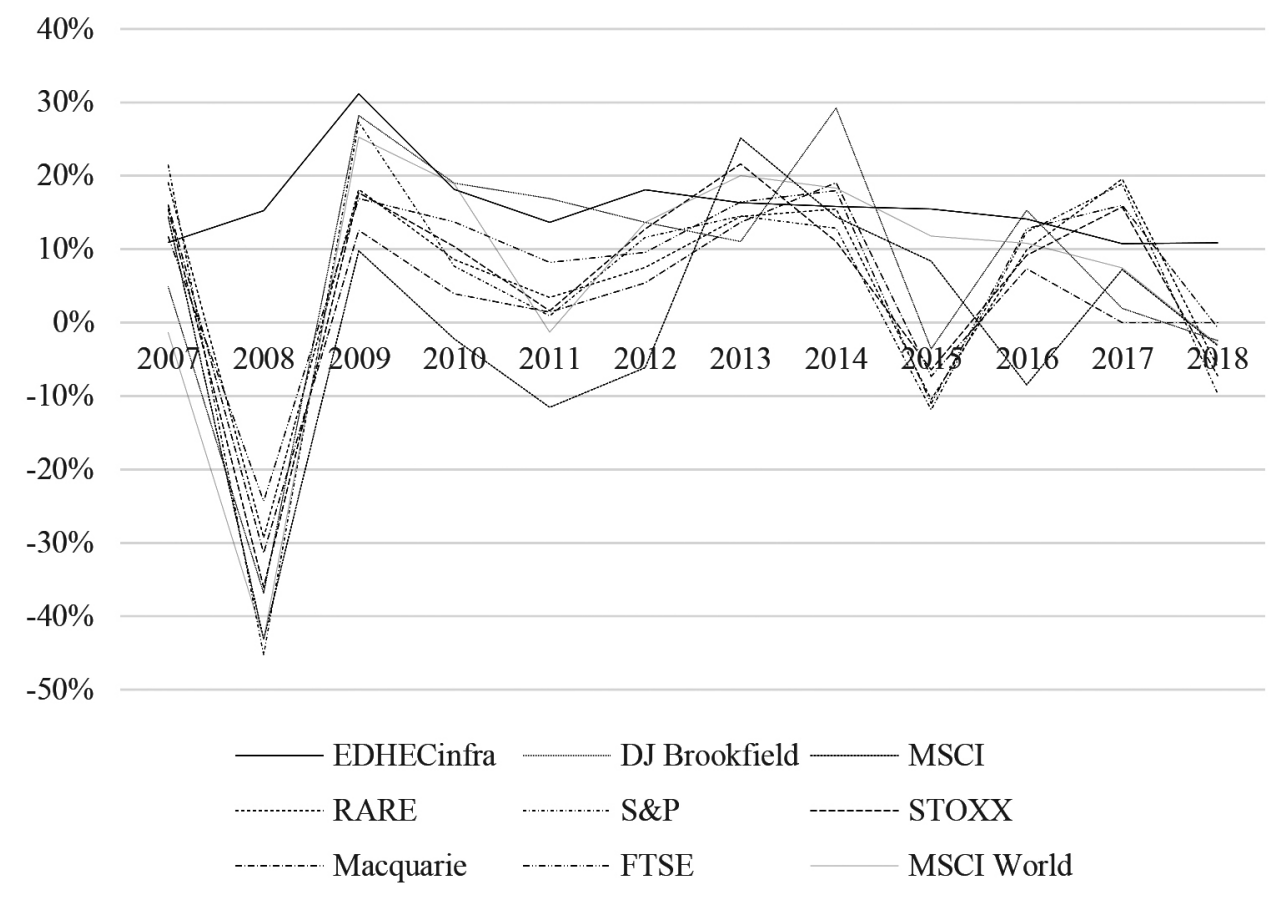

Source: Author's calculation based on Bloomberg (2019).

under management (AuM), reveals that the initial allocation accounts for at least $90 \%$ of the variability in portfolio returns. Therefore, the outperformance of a portfolio as a result of using a certain benchmark may be subjective, as the use of inadequate or irrelevant benchmarks can lead to a false representation of the investor's performance.

Private infrastructure (i.e., EDHECinfra) delivers consistently higher returns compared to listed infrastructure (i.e., DJ Brookfield, MSCI, RARE, S\&P, STOXX, Macquarie, FTSE) and global equities (i.e., MSCI World). A cumulative return analysis (see Figure 1) shows that private infrastructure was the only index that reported positive returns during the 2007-2008 period, while the EDHECinfra index's performance further improved in the aftermath of the GFC period. Even though the overall pattern of returns was relatively analogous in the period 2007-2018, the DJ Brookfield has delivered the most effective performance of the listed indices.

\section{B. Risk level}

Volatility is used as the primary measure of risk in the portfolio and is measured by the annualized standard deviation. Unlisted infrastructure has overall a lower volatility compared to listed infrastructure and global equities, as shown in Table 3. The risk level of the EDHECinfra universe contains standard deviations consistently around
$1 \%$, whereas the listed proxies report volatility levels between $4.8 \%$ and $11.4 \%$ and between $10.3 \%$ and $12 \%$ for listed infrastructure and global equities, respectively.

Table 3. Annualized Risk

\begin{tabular}{llllll} 
& 3 years & 5 years & 10 years & 12 years & 18 years \\
\hline EDHECinfra & $0.7 \%$ & $1.1 \%$ & $1.3 \%$ & $1.3 \%$ & $1.2 \%$ \\
\hline DJ Brookfield & $9.1 \%$ & $9.5 \%$ & $9.1 \%$ & $9.3 \%$ & $9.1 \%$ \\
\hline MSCI & $4.8 \%$ & $6.0 \%$ & $8.8 \%$ & $8.8 \%$ & $10.7 \%$ \\
\hline RARE & $6.2 \%$ & $6.1 \%$ & $9.2 \%$ & $9.1 \%$ & $9.1 \%$ \\
\hline S\&P & $6.9 \%$ & $7.0 \%$ & $11.4 \%$ & $10.9 \%$ & $10.7 \%$ \\
\hline STOXX & $5.6 \%$ & $5.9 \%$ & $9.6 \%$ & $9.2 \%$ & $9.2 \%$ \\
\hline Macquarie & $10.4 \%$ & $6.9 \%$ & $8.3 \%$ & $8.4 \%$ & $9.0 \%$ \\
\hline FTSE & $6.4 \%$ & $5.7 \%$ & $8.2 \%$ & $8.1 \%$ & $8.0 \%$ \\
\hline MSCI World & $10.3 \%$ & $10.7 \%$ & $11.3 \%$ & $11.4 \%$ & $12.0 \%$ \\
\hline
\end{tabular}

Source: Author's calculation based on Bloomberg (2019).

The rolling 12-month annualized standard deviation in Figure 3 shows that both listed infrastructure and global equities (i.e., MSCI World) have been consistently riskier than the unlisted EDHECinfra infrastructure index. However, the volatility of the global listed infrastructure indices is not constant and has shown considerable variation since 2007, particularly during the height of GFC. 
Figure 2. Rolling 12-Month Annualized Risk since 2007

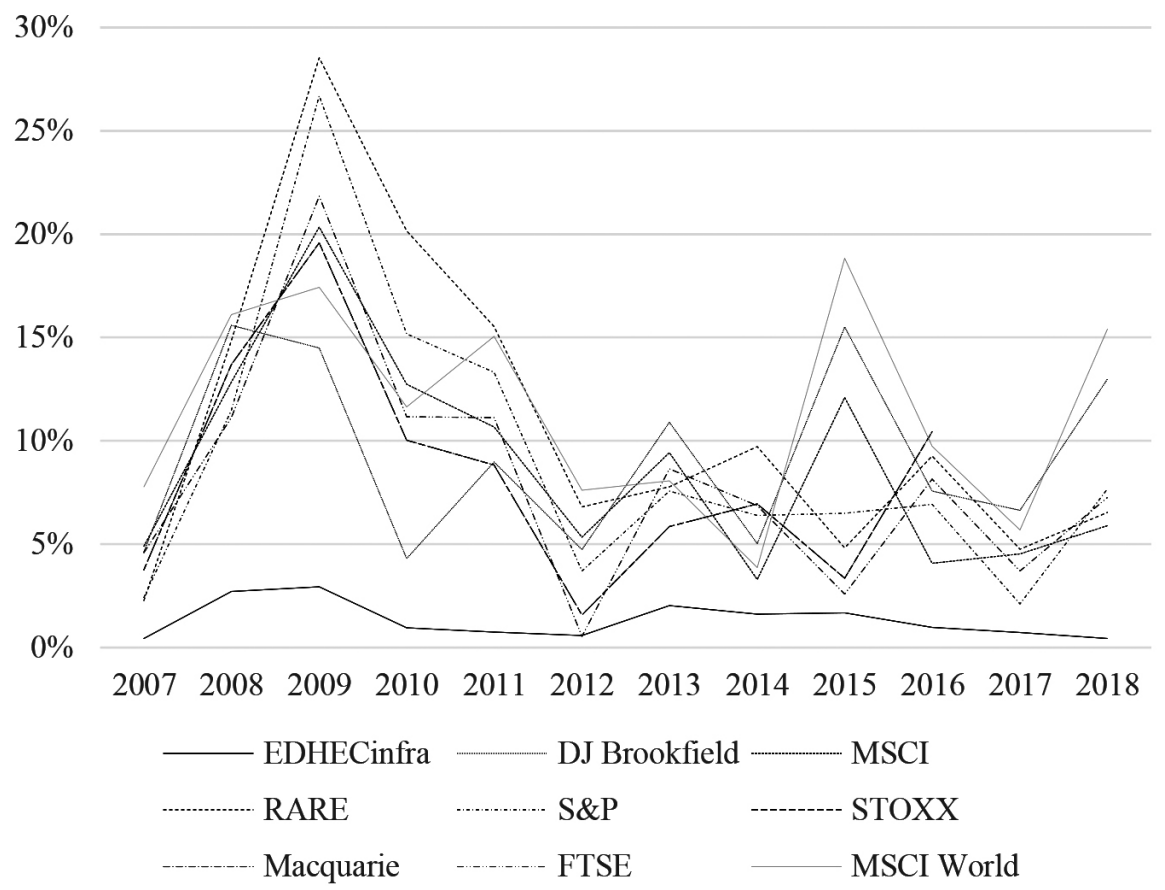

Source: Author’s calculation based on Bloomberg (2019).

\section{Risk-adjusted Performance}

Given the strong performance and lower volatility, EDHECinfra unlisted infrastructure has outperformed its listed proxies (both MSCI World and global infrastructure indices) on a risk-adjusted performance basis rated by the Sharpe ratio. Also known as the Sharpe index (named after William F. Sharpe), this ratio measures the excess return or risk premium per unit of deviation (Chan, 2009). It is a calculation of return simply divided by volatility and taking into account a risk-free rate of $-0.346 \%$ as of

Table 4. Risk-Adjusted Performance

\begin{tabular}{lccccc} 
& 3 years & 5 years & 10 years & 12 years & 18 years \\
\hline EDHECinfra & 18.56 & 15.03 & 16.38 & 16.27 & 20.58 \\
\hline DJ Brookfield & 0.75 & 1.59 & 2.03 & 1.59 & 1.98 \\
\hline MSCI & -0.27 & 0.88 & 0.53 & 0.42 & 0.54 \\
\hline RARE & 1.51 & 0.70 & 0.94 & 1.16 & 1.16 \\
\hline S\&P & 1.33 & 0.59 & 0.81 & 1.22 & 1.65 \\
\hline STOXX & 2.70 & 1.79 & 1.69 & 1.69 & 1.69 \\
\hline Macquarie & 0.74 & 0.48 & 1.10 & 1.09 & 1.36 \\
\hline FTSE & 1.99 & 0.90 & 2.73 & 2.32 & 2.44 \\
\hline MSCI World & 0.78 & 1.56 & 1.52 & 1.04 & 1.14 \\
\hline
\end{tabular}

Source: Author’s calculation based on Bloomberg (2019). $1^{\text {st }}$ July 2019. Table 4 shows that EDHECinfra unlisted infrastructure delivers the highest risk-adjusted return ratios over all periods covered by this analysis. Looking further into the Sharpe ratio during the 2001-2018 period, the global stock index MSCI World achieves at times a better risk-adjusted performance comparted to listed infrastructure; global stocks tend to react positively in the short term to a rising rates environment, while listed infrastructure stocks have shown less resilience to rising rates.

\section{Downside Protection}

Investment's performance is often measured in down-markets. Table 5 indicates the downside capture ratios for infrastructure indices, measured against the MSCI World index.

The downside capture ratio measures the percentage of decline in the MSCI World index (using quarterly time series) compared to both listed and unlisted global indices. The ratio is calculated by dividing the returns by the returns of the market index (i.e., MSCI World in this paper) during the down-market periods (Cox \& Goff, 2013). Over the study period (2001-2018), listed infrastructure indicated resilient returns to periods of downturns of the global MSCI equity index. On average, listed infrastructure reported a downside ratio of approx. 
52\% (average figure for listed data starting 2001), which indicates that those indices declined only 52\% as much as the MSCI World index during the entire study period. These ratios further improve in the short term (e.g., 3-year period). Meanwhile, the EDHECinfra reported virtually no declines when the global equities experienced down-times.

Table 5. Downside Capture Ratio Against MSCI World

\begin{tabular}{lccccc} 
& 3 years & 5 years & 10 years & 12 years & 18 years \\
\hline EDHECinfra & $-56 \%$ & $-62 \%$ & $-97 \%$ & $-73 \%$ & $-59 \%$ \\
\hline DJ Brookfield & $47 \%$ & $73 \%$ & $32 \%$ & $52 \%$ & $29 \%$ \\
\hline MSCI & $24 \%$ & $34 \%$ & $84 \%$ & $77 \%$ & $78 \%$ \\
\hline RARE & $-36 \%$ & $-5 \%$ & $45 \%$ & $44 \%$ & $26 \%$ \\
\hline S\&P & $-25 \%$ & $8 \%$ & $69 \%$ & $70 \%$ & $36 \%$ \\
\hline STOXX & $-3 \%$ & $17 \%$ & $57 \%$ & $55 \%$ & $32 \%$ \\
\hline Macquarie & $-36 \%$ & $-5 \%$ & $34 \%$ & $39 \%$ & $38 \%$ \\
\hline FTSE & $-30 \%$ & $1 \%$ & $30 \%$ & $32 \%$ & $17 \%$ \\
\hline
\end{tabular}

Source: Author's calculation based on Bloomberg (2019).

The paper analysis uses another measure of downside risk, namely the maximum drawdown, as shown in Table 6, which captures the maximum loss from a peak to trough of the index. As expected, the biggest drawdowns were reported during the GFC period (i.e., 2007-2008) while most of the listed infrastructure and the global equities lost half of their value (S\&P suffered the biggest drawdown, dropping 49\% from its peak). Interestingly, all global listed indices encountered negative returns with fairly similar magnitude and recovery time. Meanwhile, the unlisted global infrastructure EDHECinfra index reported no drawdowns during the entire period of study.
Table 6. Maximum Drawdown

\begin{tabular}{lccccc} 
& 3 years & 5 years & 10 years & 12 years & 18 years \\
\hline EDHECinfra & $0 \%$ & $0 \%$ & $0 \%$ & $0 \%$ & $0 \%$ \\
\hline DJ Brookfield & $-12 \%$ & $-14 \%$ & $-37 \%$ & $-37 \%$ & $-37 \%$ \\
\hline MSCI & $-21 \%$ & $-28 \%$ & $-46 \%$ & $-46 \%$ & $-46 \%$ \\
\hline RARE & $-6 \%$ & $-10 \%$ & $-38 \%$ & $-38 \%$ & $-38 \%$ \\
\hline S\&P & $-10 \%$ & $-14 \%$ & $-49 \%$ & $-49 \%$ & $-49 \%$ \\
\hline STOXX & $-7 \%$ & $-8 \%$ & $-43 \%$ & $-43 \%$ & $-43 \%$ \\
\hline Macquarie & $-6 \%$ & $-7 \%$ & $-38 \%$ & $-38 \%$ & $-38 \%$ \\
\hline FTSE & $-4 \%$ & $-11 \%$ & $-34 \%$ & $-34 \%$ & $-34 \%$ \\
\hline MSCI World & $-12 \%$ & $-12 \%$ & $-47 \%$ & $-47 \%$ & $-47 \%$ \\
\hline
\end{tabular}

Source: Author's calculation based on Bloomberg (2019).

\section{E. Diversification}

Diversification is one of the key considerations for long-term investors when contemplating infrastructure investments. When sufficiently diversified from global equities, listed infrastructure can be used as a defensive equity strategy, targeted to provide strong returns and reduce overall portfolio risk. As illustrated in Table 7, listed infrastructure has shown less than perfect, but relatively high correlation to global equities (DJ Brookfield reports the highest correlation of 0.83 relative to MSCI World). This correlation further decreases to approx. 0.21 for unlisted infrastructure when compared to MSCI World global equities. In particular, the analysis reports that EDHECinfra has indicated a fairly similar correlation to other listed infrastructure proxies, varying between 0.06 and 0.19 for MSCI, RARE and DJ Brookfield indices, respectively.

Please note that all correlation coefficients are calculated based on quarterly total return data for the period from $30^{\text {th }}$ June 2007 to 30 ${ }^{\text {th }}$ April 2019.

Table 7. Correlation Matrix (since 2007)

\begin{tabular}{lccccccccc} 
& $\begin{array}{c}\text { EDHEC } \\
\text { infra }\end{array}$ & DJ Brookfield & MSCI & RARE & S\&P & STOXX & Macquarie & FTSE & $\begin{array}{c}\text { MSCI } \\
\text { World }\end{array}$ \\
\hline EDHECinfra & 1.00 & 0.19 & 0.06 & 0.06 & 0.12 & 0.10 & 0.11 & 0.09 & 0.21 \\
\hline DJ Brookfield & 0.19 & 1.00 & 0.61 & 0.66 & 0.63 & 0.66 & 0.72 & 0.75 & 0.83 \\
\hline MSCI & 0.06 & 0.61 & 1.00 & 0.72 & 0.75 & 0.78 & 0.77 & 0.66 & 0.70 \\
\hline RARE & 0.06 & 0.66 & 0.72 & 1.00 & 0.98 & 0.96 & 0.94 & 0.96 & 0.63 \\
\hline S\&P & 0.12 & 0.63 & 0.75 & 0.98 & 1.00 & 0.97 & 0.92 & 0.92 & 0.65 \\
\hline STOXX & 0.10 & 0.66 & 0.78 & 0.96 & 0.97 & 1.00 & 0.94 & 0.94 & 0.70 \\
\hline Macquarie & 0.11 & 0.72 & 0.77 & 0.94 & 0.92 & 0.94 & 1.00 & 0.95 & 0.64 \\
\hline FTSE & 0.09 & 0.75 & 0.66 & 0.96 & 0.92 & 0.94 & 0.95 & 1.00 & 0.67 \\
\hline MSCI World & 0.21 & 0.83 & 0.70 & 0.63 & 0.65 & 0.70 & 0.64 & 0.67 & 1.00 \\
\hline
\end{tabular}

Source: Author's calculation based on Bloomberg (2019). 
Table 8. Beta and Systematic Risk Compared to MSCI World Index

\begin{tabular}{lccccccccc} 
& $\begin{array}{c}\text { EDHEC } \\
\text { infra }\end{array}$ & D Brookfield & MSCI & RARE & S\&P & STOXX & Macquarie & FTSE & MSCI World \\
\hline Return & $15.9 \%$ & $9.2 \%$ & $1.0 \%$ & $6.4 \%$ & $5.7 \%$ & $6.6 \%$ & $3.6 \%$ & $7.9 \%$ & $7.5 \%$ \\
\hline Volatility & $3.0 \%$ & $14.0 \%$ & $13.3 \%$ & $13.2 \%$ & $16.5 \%$ & $14.1 \%$ & $12.1 \%$ & $12.0 \%$ & $15.6 \%$ \\
\hline Sharpe ratio & 5.33 & 0.68 & 0.10 & 0.51 & 0.37 & 0.49 & 0.33 & 0.69 & 0.51 \\
\hline Downside & $0.5 \%$ & $5.0 \%$ & $5.2 \%$ & $4.9 \%$ & $5.9 \%$ & $5.6 \%$ & $4.8 \%$ & $4.3 \%$ & $5.5 \%$ \\
\hline VaR & $2.5 \%$ & $-8.2 \%$ & $-11.2 \%$ & $-11.8 \%$ & $-15 \%$ & $-12.1 \%$ & $-12 \%$ & $-8.6 \%$ & $-11.3 \%$ \\
\hline Variance & 0.0002 & 0.0049 & 0.0044 & 0.0044 & 0.0068 & 0.0050 & 0.0037 & 0.0036 & 0.0060 \\
\hline Beta & 0.04 & 0.74 & 0.60 & 0.54 & 0.69 & 0.63 & 0.49 & 0.52 & $\mathrm{n} / \mathrm{a}$ \\
\hline Unsystematic & $1.50 \%$ & $3.99 \%$ & $4.79 \%$ & $5.18 \%$ & $6.35 \%$ & $5.08 \%$ & $4.74 \%$ & $4.50 \%$ & $\mathrm{n} / \mathrm{a}$ \\
\hline
\end{tabular}

Source: Author’s calculation based on Bloomberg (2019).

\section{F. Equity Market Beta}

Usually, benchmarks are expected to represent the broad characteristics of individual asset classes over a certain period of time in order to determine the overall portfolio weights and the corresponding asset allocations. Beta represents the volatility of an investment to movements in equity markets. A beta of more than 1 represents greater volatility or sensitivity to the market investments; in other words, it means that if the market moves up or down by $1 \%$, the investment will move by more than $1 \%$, and vice versa. Calculating equity market beta is considered a valuable sensitivity of an investment shift within the equity market. The linear regression method helps determine the beta with the dependent variable performance and the performance of the index.

Using a regression model of the indices' data as of $30^{\text {th }}$ July 2007, analysis shows that infrastructure stocks have consistently maintained a beta of less than 0.75 , as indicated in Table 8. The calculation was done by computing the excess return of each index and the excess market return (i.e., MSCI World), and by subtracting the risk-free benchmark (i.e., 3-month Euribor of -0.346 as of $1^{\text {st }}$ July 2019). Please note that approximately half of the calculated data as a percentage of variation in excess returns could be explained by the regression model. For investors seeking low-risk investment strategies, a beta of less than 1 would be highly advisable.

Following the logic of the capital asset pricing model (CAPM, see Milne, 1995), which provides a diversified portfolio in a perfect and efficient economic system solely based on the systematic risk of the return, the underlying analysis looks further into the measure of variation in risk index returns that are not explained by the beta calculation. As illustrated in Table 8, the EDHECinfra index has shown the lowest unsystematic risk of $1.50 \%$ when compared to the global listed proxies reported between $4 \%$ and $6.38 \%$.

\section{Conclusion}

Listed infrastructure indices are often considered the preferred relative benchmarks for many investors (Amenc et al., 2019). Empirical findings struggle to support the definition of infrastructure as an asset class (Bianchi \& Drew, 2014), while others go even further by calling investments in the listed infrastructure universe a 'fake' infrastructure (Amenc et al., 2017). This paper shows the misrepresentation of commonly used global listed infrastructure indices and the significance of implying proper benchmarking across the investment portfolio.

The comparison of global listed infrastructure indices with the unlisted EDHECinfra index has highlighted the importance of a multicriteria classification system, which is focused specifically on infrastructure-related industrial activities (including the various levels of complexity, size and scale). A review of listed infrastructure index constituents has indicated that the GICS standard industrial classification can be inferiorly positioned to represent the different types of infrastructure companies, often including companies with broad industrial nature and less relevant business activities to infrastructure. The newly introduced TICCS system used in the EDHECinfra index methodology allows for building more adequate benchmarks. A proper benchmark should warrant various industrial activities with individual classifications as the role of difference business models and types of regulation in the segmentation of the infrastructure sectors can be substantially different.

Pricing across illiquid asset classes such as infrastructure equity is often driven by systematic factors, including investors making choices based on perceived risk and the respective price in exchange for that risk. The paper indicates that listed infrastructure has a significantly higher correlation than EDHECinfra unlisted index relative to the broad market MSCI World index. The unlisted universe of stocks 
in the EDHECinfra index has consistently delivered superior risk-adjusted returns and lower volatility when compared to the listed proxies.

Current listed benchmarks are flawed in their ability to identify the systematic rewarded risks, monitor the risk-adjusted performance or set risk budgets, as the unlisted benchmark has provided better downside protection in falling equity markets and better diversification to global equities. The performance of global listed indices has not delivered an adequate representation of the asset class when compared with an unlisted infrastructure proxy. Amid the growing popularity of infrastructure investments among investors, the overall representation of the asset class may be diminished in search of yield. This paper sets the groundwork for further research possibilities on benchmarking infrastructure investments by examining the unlisted investment space.

\section{References}

Amenc, N., Blanc-Brude, F., Chreng, A., \& Tran, C. (2017). The rise of "fake infra": The unregulated growth of listed infrastructure and the dangers it poses to the future of infrastructure investing. Singapore: EDHEC Infrastructure Institute.

Amenc, N., Blanc-Brude, F., Gupta, A., \& Yim, J. (2019). Global infrastructure investor survey: Benchmarking trends and best practices. Singapore: EDHEC Infrastructure Institute.

Bianchi, R., \& Drew, M. (2014). Is infrastructure an asset class? An asset pricing approach. Queensland: Griffith Business School.

Blanc-Brude, F., \& Whittaker, T. (2015). Listed proxies of private infrastructure equity: Performance, risk measures and representativity. Singapore: EDHEC Infrastructure Institute.

Blanc-Brude, F., Chreng, A., Hasan, M., Wang, Q., \& Whittaker, T. (2017). Private infrastructure broad market equity indices: Benchmarking Europe's private infrastructure equity investments 2000-2016. EDHEC Singapore: EDHEC Infrastructure Institute.

Chan, E. (2009). Quantitative trading: How to build your own algorithmic trading business. New Jersey: John Wiley \& Sons.

Cox, D. R., \& Goff, D. C. (2013). Capture ratios: A popular method of measuring portfolio performance in practice. Appalachian State University. Departments of Finance, Banking and Insurance. Journal of Economics and Finance Education, 12(2).

Della Croce, R., Paula, J., \& Laboul, A. (2015). Infrastructure financing instruments and incentives. Paris: OECD.

EDHEC (2018). Infrastructure indices methodology standards: Unlisted equity \& private infrastructure debt. Singapore: EDHEC Infrastructure Institute.

Euribor (online). 3-Month Euribor rates. Retrieved from: https://www.euribor-rates.eu/euribor-rate-3-months.asp

European Commission (EC) (2016). Amendment Delegated Regulation (EU) 2015/35 concerning the calculation of regulatory capital requirements for several categories of assets held by insurance and reinsurance undertakings. 2016/467.

European Commission (EC) (2017). Amendment Delegated Regulation (EU) 2015/35 concerning the calculation of regulatory capital requirements for certain categories of assets held by insurance and reinsurance undertakings (infrastructure corporates). C(2017) 3673 final.

FTSE Russell (2019). FTSE core infrastructure indexes - factsheet. FTSE Russell.

Geysen, A. (2018). The role of infrastructure in a portfolio. Vanguard Research.

Inderst, G. (2010). Infrastructure as an asset class. European Investment Bank (EIB) Papers, 15(1).

Legg Mason (2017). Infrastructure indices: A comparison of performance. Legg Mason Global Asset Management Hong Kong Limited.

Macquarie (2005). Macquarie global infrastructure index - fact sheet. Macquarie Group.

Milne, F. (1995). Finance theory and asset pricing. Oxford: Claredon Press.

MSCI (2017). MSCl infrastructure indexes methodology. MSCI Indices.

MSCI (2019). MSCl global investable market indexes methodology: Index construction objectives, guiding principles and methodology. MSCI Indices.

Moody's (2018). Default and recovery rates for project finance bank loans 1983-2017. Moody's Investors Service.

Moss, A. (2014). Infrastructure investment: Combining listed with unlisted. Consilia Capital. https://doi.org/10.2139/ssrn.2616634

Newell, G., Peng, H., \& De Francesco, A. (2011). The Performance of unlisted infrastructure in investment portfolios. Journal of Property Research. https://doi.org/10.1080/09599916.2011.544149

OECD (2002). Glossary of statistical terms: Infrastructure. Retrieved from https://stats.oecd.org/glossary/detail.asp?ID=4511

Oyedele, J., Adair, A., \& McGreal, S. (2012). Performance of global listed infrastructure investment in a mixed asset portfolio. Journal of Property Research, 31(1). https://doi.org/10.1080/09599916.2013.832592

Standard and Poor's (2019). S\&P thematic indices methodology. Standard and Poor's Dow Jones Indices: Index Methodology.

Standard and Poor's Dow Jones Indices (2019). Dow Jones Brookfield infrastructure indices methodology. S\&P Dow Jones Indices.

STOXX (2019). STOXX index methodology guide (portfolio based indices). STOXX Indices.

World Bank (online). Private participation in infrastructure database: Methodology/glossary/segment. Retrieved from: https://ppi.worldbank. org/methodology/glossary 
Appendix A: TICCS Classification (EDHEC Institute)

\begin{tabular}{|c|c|c|c|}
\hline Superclass & Class & Sub-Class & Example \\
\hline \multirow[t]{5}{*}{ Business risk (BR) } & BR1 - contracted & BR10 - fully contracted & availability-based, take-or-pay offtake agreements, feed-in tariff \\
\hline & & BR11 - partially contracted & (shadow) toll, partial capacity, partial power purchase agreement \\
\hline & BR2 - merchant & BR20 - variable & real toll roads, merchant power plants \\
\hline & BR3 - regulated & BR30 - rate-of-return regulation & cost-of-service regulation, commission regulation (US) \\
\hline & & BR31 - price-cap regulation & incentive regulation \\
\hline \multirow[t]{32}{*}{ Industrial (IC) } & IC10 - power generation & IC1010 - independent power & nuclear, gas, coal, combined heat and power generation \\
\hline & & $\begin{array}{l}\text { IC1020 - independent water and } \\
\text { power }\end{array}$ & power and water production \\
\hline & IC20 - environmental services & IC2010 - solid waste treatment & (non)hazardous waste treatment, waste-to-power generation \\
\hline & & IC2020 - water treatment & $\begin{array}{l}\text { potable \& industrial water, sea water desalination, water supply } \\
\text { dams }\end{array}$ \\
\hline & & IC2030 - wastewater treatment & residential \& industrial wastewater and reuse \\
\hline & & IC2040 - environmental management & flood control, coastal and riverine locks, energy efficiency \\
\hline & IC30 - social infrastructure & IC3010 - defence services & strategic transport and refueling, training facilities, barracks \\
\hline & & IC3020 - education services & schools, universities, student accommodation \\
\hline & & IC3030 - government services & police stations, courts of justice, prisons, street lighting, offices \\
\hline & & IC3040 - health 6 social care services & hospitals, clinics, residential and assisted living \\
\hline & & IC3050 - recreational facilities & stadiums, convention centers, public parks, libraries, museums \\
\hline & IC40 - energy and water resource & sIC4010 - pipeline & gas, oil, water, wastewater pipelines \\
\hline & & IC4020 - energy resource processing & liquefied natural gas (LNG) liquefaction and regasification \\
\hline & & IC4040 - energy resource storage & gas, liquid storage \\
\hline & IC50 - data infrastructure & IC5010 - data transmission & telecom towers, long-distance cables, satellites \\
\hline & & IC5020 - data storage & data centers \\
\hline & IC60 - transport & IC6010 - airport & airports \\
\hline & & IC6020 - car park & car parks \\
\hline & & IC6030 - port & tool ports, container ports \\
\hline & & IC6040 - rail & heavy rail lines \\
\hline & & IC6050 - road & motorways, roads, tunnels, bridges \\
\hline & & IC6060 - urban commuter & urban light-rail, bus, underground/overground mass transit \\
\hline & IC70 - renewable power & IC7010 - wind power generation & on-shore, off-shore wind \\
\hline & & IC7020 - solar power generation & photovoltaic, thermal solar power \\
\hline & & IC7030 - hydroelectric power generation & ndam, run-of-river power, pumped hydroelectric storage \\
\hline & & IC7040 - other renewable power & biomass, geothermal, wave power \\
\hline & & IC7050 - other renewable technologies & sbattery storage, off-shore transmission (OFTO) \\
\hline & IC80 - network utilities & IC8010 - electricity distribution & electricity distribution networks \\
\hline & & IC8020 - electricity transmission & electricity transmission networks \\
\hline & & IC8030 - district cooling/heating & district cooling/heating networks \\
\hline & & IC8040 - water and sewerage & water and sewerage networks \\
\hline & & IC8050 - gas distribution & gas distribution networks \\
\hline \multirow[t]{4}{*}{ Geo-economic (GE) } & GE1 - global infrastructure & & major transportation hubs, exposure to global commodity prices \\
\hline & GE2 - regional infrastructure & & medium-size container ports, transborder road corridor \\
\hline & GE3 - national infrastructure & & large-scale road or telecommunication networks \\
\hline & GE4 - subnational infrastructure & & municipal or other subsovereign-entity social infrastructure \\
\hline \multirow[t]{4}{*}{ Corporate-governan } & CG1 - infra project companies & CG10 - monitored project companies & special-purpose vehicle (SPV), single-project company \\
\hline & & CG11 - unmonitored project companies & sless than $50 \%$ of debt provided by external senior creditors \\
\hline & CG2 - infrastructure corporates & CG20 - monitored infra corporates & multi-project companies \\
\hline & & CG21 - unmonitored infra corporates & less than $50 \%$ of debt provided by external senior creditors \\
\hline
\end{tabular}


Appendix B: GICS Classification (infrastructure-relevant sectors only)

\begin{tabular}{|c|c|c|c|}
\hline Sector & Industry Group & Industry & Sub-industry \\
\hline \multirow[t]{7}{*}{10 - energy } & 1010 - energy & 101010 - energy equipment \& services & oil \& gas drilling, equipment services \\
\hline & & 101020 - oil, gas and consumable fuels & $\begin{array}{l}\text { exploration, production, refining, storage and } \\
\text { transportation }\end{array}$ \\
\hline & 1510 - materials & 151010 - chemicals & commodity, agricultural, industrial gases \\
\hline & & 151020 - construction materials & construction materials \\
\hline & & 151030 - containers and packaging & metal \& glass containers, paper packaging \\
\hline & & 151040 - metals and mining & aluminum, copper, gold, silver, steel, etc. \\
\hline & & 151050 - paper and forest & paper \& forest products \\
\hline \multirow[t]{14}{*}{20 - industrials } & 2010 - capital goods & 201010 - aerospace \& defense & \\
\hline & & 201020 - building products & \\
\hline & & 201030 - construction and engineering & \\
\hline & & 201040 - electrical equipment & (heavy) electrical components and equipment \\
\hline & & 201050 - industrial conglomerates & \\
\hline & & 201060 - machinery & $\begin{array}{l}\text { construction machinery and heavy trucks, } \\
\text { industrial, agricultural }\end{array}$ \\
\hline & & 201070 - trading companies \& distribute & trading companies and distributors \\
\hline & 2020 - commercial and professional services & 202010 - commercial services \& supplies & \\
\hline & & 202020 - professional services & \\
\hline & 2030 - transportation & 203010 - airfreight and logistics & \\
\hline & & 203020 - airlines & \\
\hline & & 203030 - marine & \\
\hline & & 203040 - road and rail & railroads, trucking \\
\hline & & 203050 - transportation infrastructure & $\begin{array}{l}\text { airport services, highway \& railtracks, marine } \\
\text { ports and services }\end{array}$ \\
\hline \multirow[t]{11}{*}{25 - consumer discretionar } & 2510 - automobiles and components & 251010 - auto components & auto parts and equipment \\
\hline & & 251020 - automobiles & automobile/motorcycle manufacturers \\
\hline & 2520 - consumer durables and apparel & 252010 - household durables & \\
\hline & & 252020 - leisure products & \\
\hline & & 252030 - textiles, apparel \& luxury good & \\
\hline & 2530 - consumer services & 253010 - hotels, restaurants and leisure & \\
\hline & & 253020 - diversified consumer services & \\
\hline & 2550 - retailing & 255010 - distributors & \\
\hline & & 255020 - internet \& direct marketing & \\
\hline & & 255030 multiline retail & \\
\hline & & 255040 - specialty retail & \\
\hline \multirow[t]{6}{*}{30 - consumer staples } & 3010 - food and staples retailing & 301010 - food and staples & drug retail, food distributors, hypermarkets \\
\hline & 3020 - food, beverage and tobacco & 302010 - beverages & brewers, soft drinks, distillers and vintners \\
\hline & & 302020 - food products & agricultural, packaged foods and meats \\
\hline & & 302030 - tobacco & \\
\hline & 3030 - households and personal products & 303010 - household products & \\
\hline & & 303020 - personal products & \\
\hline \multirow[t]{6}{*}{35 - health care } & 3510 - health care equipment and services & 351010 - health care equipment/supply & \\
\hline & & 351020 - health care providers/services & \\
\hline & & 351030 - health care technology & \\
\hline & $\begin{array}{l}3520 \text { - pharmaceuticals, biotechnology and } \\
\text { life sciences }\end{array}$ & 352010 - biotechnology & \\
\hline & & 352020 - pharmaceuticals & \\
\hline & & 352030 - life science tools \& services & \\
\hline \multirow[t]{3}{*}{40 - financials } & 4010 - banks & 401010 - banks & \\
\hline & & 401020 - trusts and mortgage finance & \\
\hline & 4020 - diversified financials & 402010 - diversified financial services & \\
\hline
\end{tabular}


Appendix B: GICS Classification (infrastructure-relevant sectors only) (continued)

\begin{tabular}{|c|c|c|c|}
\hline \multirow[t]{5}{*}{ Sector } & Industry Group & Industry & Sub-industry \\
\hline & & 402020 - consumer finance & \\
\hline & & 402030 - capital markets & \\
\hline & & 402040 - mortgage REITs & \\
\hline & 4030 - insurance & 403010 - insurance & \\
\hline \multirow[t]{6}{*}{$\begin{array}{l}45 \text { - information } \\
\text { technology (IT) } \\
\end{array}$} & 4510 - software and services & 451020 - IT services & \\
\hline & & 451030 - software & \\
\hline & 4520 - technology hardware & 452010 - communication equipment & \\
\hline & & 452020 - technology hardware & \\
\hline & & 452030 - electronic equipment & \\
\hline & 4530 - semiconductors/equipment & 453010 - semiconductors/equipment & \\
\hline \multirow{2}{*}{\multicolumn{2}{|c|}{50 - communication services 5010 - telecommunication services }} & 501010 - diversified telecom services & alternative carriers, integrated telecom services \\
\hline & & 501020 - wireless telecom services & \\
\hline & 5020 - media and entertainment & 502010 - media & advertising, broadcasting, cable and satellite \\
\hline & & 502020 - entertainment & movies, entertainment \\
\hline & & 502030 - interactive media and services & \\
\hline \multirow[t]{5}{*}{55 - utilities } & 5510 - utilities & 551010 - electric utilities & \\
\hline & & 551020 - gas utilities & \\
\hline & & 551030 - multi-utilities & \\
\hline & & 551040 - water utilities & \\
\hline & & 551050 - power \& renewable producers & $\begin{array}{l}\text { independent power producers and energy } \\
\text { traders; renewable energy }\end{array}$ \\
\hline \multirow[t]{2}{*}{60 - real estate } & 6010 - real estate & 601010 - REITS & $\begin{array}{l}\text { diversified, industrial, office, health care, } \\
\text { residential, retail, etc. }\end{array}$ \\
\hline & & $\begin{array}{l}601020 \text { - real estate management and } \\
\text { development }\end{array}$ & RE operating companies, development, services \\
\hline
\end{tabular}

\section{Indeksi infrastrukture: primerjalna analiza uspešnosti, tveganja in reprezentativnosti globalno objavljenih ocen}

\section{Izvleček}

Soočeni z zgodovinsko nizkimi obrestnimi merami investitorji v iskanju alternativnih virov zaslužkov, boljše diverzifikacije in dolgoročne investicijske perspektive še nadalje raziskujejo nelikvidno premoženje, kot je infrastruktura. Ta članek analizira ključne značilnosti uspešnosti in tveganj globalno objavljenega infrastrukturnega indeksa EDHECinfra $v$ primerjavi s ključnimi globalno objavljenimi infrastrukturnimi indeksi v obdobju 2001-2018. Za določitev reprezentativnosti običajno uporabljenih benchmarkingov infrastrukturnih investicij med investitorji smo uporabili deskriptivno statistiko. Z namenom tržne beta analize $v$ linearnem regresijskem modelu uporabimo tudi MSCI World Index kot oceno globalnih delnic.

V indekse vključena infrastruktura je pogosto obravnavana kot dohodkovni donos in obrambna lastniška strategija, ki zagotavlja likvidno oceno za alternativno premoženje (npr. infrastrukturo). Vendar pa rezultati v članku nakazujejo, da neto učinek investiranja v objavljen infrastrukturni indeks ostaja vprašljiv, celo neznan. Nedavni empirični rezultati kažejo različne poglede na benchmarking infrastrukture. Visoka korelacija ključnih objavljenih indeksov infrastrukture s širokim indeksom lastniškega kapitala MSCI World in nekonsistentnost raziskovalnih rezultatov tako močno nakazujeta, da je infrastruktura šibko definirana investicijska kategorija z manjkajočimi zanesljivimi in uporabnimi benchmarkingi. Običajno uporabljena in daljnosežna razvrstitev podjetij s širokim industrijskim značajem in manj relevantnimi poslovnimi aktivnostmi za infrastrukturo lahko vpliva na splošen prikaz legitimnih značilnosti infrastrukturnega premoženja sredi naraščajočega navdušenja med investitorji.

Ključne besede: infrastruktura, indeks, benchmarking, kotirajoči lastniški kapital, analiza uspešnosti 